\title{
Diagnostic criteria for lessivage of profile-differentiated soils of the Precarpathian region (Ukraine)
}

\section{Diagnostizierende Kriterien der Lessivierung von profildifferenzierten Böden der vorkarpatischen Region (Ukraine)}

\author{
Zenoviy Pankiv, Stepan Malyk, Taras Yamelynets*
}

Geography Department, Ivan Franko National University of Lviv, Doroshenka str. 41, 79000 Lviv, Ukraine

* Corresponding author: taras.yamelynets@lnu.edu.ua

Received: 17 June 2019, received in revised form: 10 September 2019, accepted: 11 September 2019

\begin{abstract}
Summary
Profile-differentiated soils of the Precarpathian region were formed due to the combined effect of such processes as podzolization, lessivage, gley-eluvium. For the diagnosis of these soils, researchers have used different diagnostic features. The most controversial is the diagnosis of the lessivage process. Based on our own field and analytical studies, it is suggested to use the granulometric composition compared to the contents of the horizon and the silt content in argillanes for the diagnosis of lessivage argillanes within the illuvial horizon. A reliable feature of lessivage is the equal distribution of the montmorillonite group minerals within the profile, which is diagnosed by the ratio of $\mathrm{SiO}_{2}: \mathrm{Al}_{2} \mathrm{O}_{3}$ in the silty fraction, the accumulation of $\mathrm{Fe}_{2} \mathrm{O}_{3}$ and $\mathrm{R}_{2} \mathrm{O}_{3}$ in the illuvial horizon in comparison with the rock and positive values of eluvial-accumulative coefficient of oxides in the silty fraction in the illuvial part of the soil profile.
\end{abstract}

Keywords: Argillanes, Schlufffraktion, granulometric composition, podsolization, montmorillonite group minerals

\section{Zusammenfassung}

Profildifferenzierte Böden der vorkarpatischen Region bildeten sich aufgrund der kombinierten Wirkung von Prozessen der Podsolierung, Lessivierung und Gley-Eluvium. Für deren Diagnose verwenden Wissenschaftler unterschiedliche diagnostische Merkmale. Am umstrittensten ist die Diagnose des Lessivierungsprozesses. Auf Grundlage eigener Felderhebungen und analytischer Untersuchungen wird vorgeschlagen, granulometrische Zusammensetzung im Vergleich zu den Horizontgehalten und die Schluffgehalte in den Argilinen für die Lessivierungsdiagnose innerhalb des Illuvialhorizonts zu benutzen. Ein zuverlässiges Zeichen für die Lessivierung ist die gleichmäßige Verteilung der Minerale der Montmorillonit-Gruppe innerhalb des Profils. Dies wird anhand des Verhältnisses $\mathrm{SiO}_{2}: \mathrm{Al}_{2} \mathrm{O}_{3}$ in der Schlufffraktion, der Akkumulation von $\mathrm{Fe}_{2} \mathrm{O}_{3}$ und $\mathrm{R}_{2} \mathrm{O}_{3}$ im illuvialen Horizont im Vergleich zum Gestein und positiver Werte bei den Eluvialkoeffizienten der Oxide in der Schlufffraktion im illuvialen Teil des Bodenprofils diagnostiziert.

Schlagworte: Argillane, Schlufffraktion, Granulometrie, Podsolisierung, Montmorillonit-Gruppe des Minerals 


\section{Introduction}

The formation of a variegated soil cover within the Precarpathian soil-geographic region, which is situated between the southwestern edge of the Podillya Highland and the northeastern slope of the Ukrainian Carpathians, evokes contentious debates about the pedogenesis and classification status (Andrushchenko, 1970; Pankiv, 1998; Smaga, 2008). Geologically, the Precarpathian region is composed of Neogene deposits and is divided into two zones: (1) the outer zone, formed on the Paleozoic and Mesozoic deposits, and (2) the inner zone, formed on the folded Flysch sediments. The soil-forming rocks of brown-podzolic soils are Quaternary deposits, which are represented mainly by former alluvial rocky sediments and eluvium-diluvium deposits. This region is located within the temperate climatic zone of the Atlantic-continental region. The annual rainfall amount is strongly related to the altitudes and significantly increases from bottom to top (from $576 \mathrm{~mm}$ to $771 \mathrm{~mm}$ accordingly). Furthermore, the washing water regime is typical for this region as the amount of sum active temperatures decrease in the same direction (from $2560{ }^{\circ} \mathrm{C}$ to $2360{ }^{\circ} \mathrm{C}$ ) and the coefficient of wetting of the territory increases at the same time (Andrushchenko, 1970). As the Precarpathian region is located between the valleys of the Svicha River in the northwest and the Luchka River in the southeast, the distribution of soils within its boundaries is caused due to high altitude. As mentioned above, the change in absolute and relative altitudes determine the changes in the climatic parameters, the level of groundwater occurrence and the types of plant formations, which altogether cause the morphological features, physical and physical-chemical properties of the soils. Soils with an eluvium-alluvium profile type, which were formed as a result of complex combination and different intensity of basic soil processes (BSP) prevail within the IV-VI of the floodplain terraces. On the basis of large-scale soil examination (1957-1961) in the Precarpathian region, two types of profile-differentiated soils were distinguished: sod-podzolic and brown-podzolic. During the period of researching podzolic soils, two hypotheses of their profile differentiation were dominating: podzolization and lessivage (Kubiena, 1956; Fridland, 1985). By the 50s of the twentieth century, the theory of soil formation under the prevailing influence of the podzolization process had mainly been dominant in the research of the Precarpathian soil. Such concepts as colloid-chemical, biochemical, physico-chemical were used to support this theory. To substan- tiate the genesis of profile-differentiated soils formed on loamy rocks, the European scientists have suggested the theory of lessivage as a process of suspension migration and illuvial accumulation of silty particles without chemical destruction (Harrassowitz, 1926; Duchaufour, 1951; Mückenhausen, 1958; Dawson, 1985).

The lessivage theory was developed in the works of the Soviet, and later, Ukrainian soil scientists. In the works devoted to the study of profile-differentiated soils of the Precarpathian region, most scholars claim that they were formed on the basis of complex processes such as podzolization, lessivage, gley-eluvium, which are supplemented by segregation, inland clay and acidic humus formation (Nazarenko, 1981; Smaga, 2016).

In profile-differentiated soils of the Precarpathian region, differentiated diagnostic indicators are used for the diagnosis of BSP, particularly lessivage. It is necessary to define a single set of diagnostic features for establishing a genesis of profile-differentiated soils in the Precarpathian region, or diagnosing the intensity of the lessivage process. The aim of the study is to establish diagnostic features of lessivage in the profile-differentiated soils of the Precarpathian Region.

\section{Materials and methods}

Based on the processing of soil maps in the Precarpathian Region, "Kamin" (515 m elevation, N 4805'58.61", E $\left.24^{\circ} 01^{\prime} 71.59^{\prime \prime}\right)$ was chosen as the study area (Figure 1). Using comparative-geographical and profile-geographical methods, three cuts in agricultural lands and three under natural biocenoses (spruce-oak forest) were made within the key area. Morphological features were studied in field conditions and soil samples were selected from the soil horizons, soil-forming rock (ancient alluvial loam) and new formations (argillanes). In laboratory conditions, the silt fraction was washed out from the soil samples by the method of N.I. Horbunov (Horbunov, 1960). The gross chemical composition was determined in soil samples, silt fractions and argillanes, according to E.V. Arynushkyna's method (Arynushkyna, 1970). The granulometric composition of the soil and argillanes were identified using N.A. Kachinsky's method with soil preparation by the pyrophosphate method according to S. Dolgovy and A. Lichmanova (Kachynsyi, 1965). On the basis of the results of the gross chemical composition of the silt, fines, argillane and molar ratios were calculated according to the method of H. Harrassowitz (indicators of profile differentiation) 


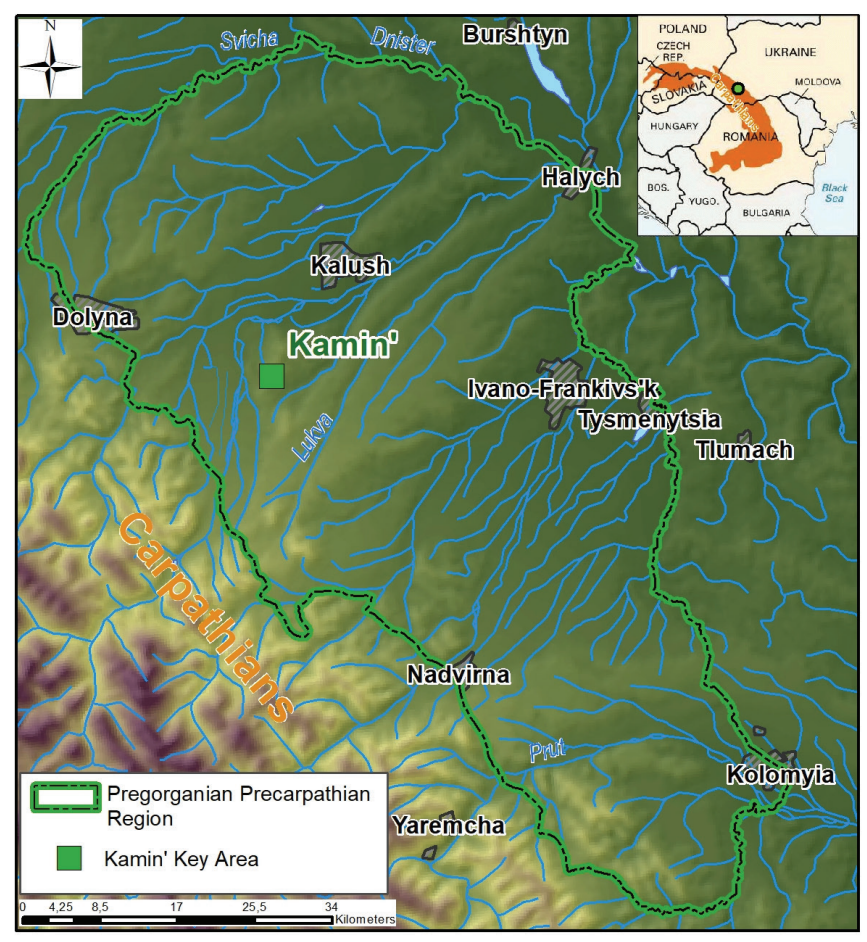

Figure 1. Location of the study region Abbildung 1. Lage der Untersuchungsregion

(Harrassowitz, 1926), "leaching factor" according to G. Jenny's method (Jenny, 1931), eluvial-accumulative coefficients (EA) of Iron(III) oxide $\left(\mathrm{Fe}_{2} \mathrm{O}_{3}\right)$, sesquioxide $\left(\mathrm{R}_{2} \mathrm{O}_{3}\right)$, EAt (total eluvial-accumulative coefficient for all oxides) and EAm (eluvial-accumulative coefficient of all oxides, except for selected oxides) according to Rode (2008). To establish the genesis of the argillanes, we calculated the accumulation coefficient (Cx) (Dawson, 1985). This coefficient shows the ratio of the content of element $(\mathrm{x})$ in the argillanes to the content of element $(\mathrm{x})$ in the soil. The content of humus was determined by the method of I.V. Tyurin (Arynushkyna, 1970). The fractional humus content was determined in the soils and total humus content in argillanes (Arynushkyna, 1970).

\section{Results}

The Precarpathian profile-differentiated soils were formed on the diluvial and ancient alluvial loamy sediments under conditions of excess moisture, stagnant-washing type of water regime under mixed and broad-leaved forests with grass cover as a result of a complex combination of soilforming processes. Due to the combined effect of soil for- mation factors, a greatly differentiated type of profile with a depleted silt, half oxides and an enriched in silica upper eluvial and enriched in silt, half oxides illuvial part of the profile was formed (Figure 2).

Formation of the genetic type of soil is conditioned by the profile-forming BSP and with the possible participation of several aggregates (Zonn, 1994). However, in profiledifferentiated soils, no single isolated soil-forming process can form the soil as a holistic natural body. Such soils are formed with the participation of certain combinations of specific BSP, but never formed by only one process (Targulyan, 1985).

In modern Ukrainian soil science, the genesis issues of the profile-differentiated soils of the Precarpathian region are the most controversial. Scientists' views on the formation of the eluvially-illiual differentiation of the profile are ambiguous due to the contradiction between the diagnostic criteria of the soil-forming processes of podzolization, lessivage, gley-eluvium, that have a similar result of their passing (Smaga, 2016).

The diagnostic criteria for the lessivage process are the most controversial ones since it has been diagnosed and studied in the soils of the Precarpathian region relatively recently. For its diagnosis, researchers use distinguished criteria: the accumulation of $\mathrm{R}_{2} \mathrm{O}_{3}$ in $\mathrm{B}$ horizon compared to the rock (Rode, 1984), the accumulation of $\mathrm{SiO}_{2}$ in $\mathrm{E}$ horizon (Fridland, 1985), the clay cutans on the surface of the pedes in B horizon and the flowing forms of clay in pores (Zaydelman, 1973; Bronnykova, 2005), the same content of montmorillonite within the profile (Smaga, 2016).

To substantiate the diagnostic criteria of the lessivage process in the profile-differentiated soils of the Precarpathian region, we have analyzed following results of our own investigations: (1) morphological research of argillanes; (2) indicators of the gross chemical composition of the soil, silt fraction, argillanes; (3) the granulometric composition of argillanes and their horizons.

Most researchers claim that profile-differentiated soils of the Precarpathian region were formed by the predominant effect of podzolization, lessivage, gluten-eluvium processes, which were supplemented by leaching, segregation, inland clay, acid humus formation (Nazarenko, 1981; Pankiv, 1998; Smaga, 2016).

Lessivage is the process of mechanical displacement of clay and colloidal material from the upper part of the soil profile and its accumulation at a certain depth in the form of local or solid formations on the pedes' surfaces, debris of rocks, or on the pore walls. The most reliable morphologi- 
cal characteristic of the lessivage process is the clay cutans, which fill cracks and cover the walls of structural divisions. Cutans is a change in the texture or deposits on the natural surfaces in soil material due to the concentration of any soil component or plasma modification in situ. According to mineralogical nature, one can differentiate between argillanes, sesquans, mangans, silanes, skeletans, and complex cutans (Rozanov, 1988).

In the process of field morphological research of profiledifferentiated soils of the Precarpathian region within the limits of the Bm g horizon on the upper and lateral surfaces of the boulders and pebbles inclusions, there have been diagnosed the argillanes of whitish, dirty-whitish coloring up to $1 \mathrm{~cm}$. The argillanes within the illuvial horizon are distinguished by coloring, scaling and have a sharp edge with the contact surface. In order to diagnose argillanes, a determination of their granulometric composition and their horizon was made (Table 1).

The results of Table 1 indicate that the granulometric composition of the argillanes is heavier compared to the contents of the horizon of $75-85 \mathrm{~cm}$, and the content of silt in argillanes is $20 \%$ higher than in the $\mathrm{Bm} \mathrm{g}$ ( $\mathrm{g}=$ gleyish) horizon, which is the result of the lessivage process. In order to diagnose the lessivage process in the profile-differentiated soils of the Precarpathian region, it is advisable to use the results of the argillane granulometric composition and the surrounding horizon, and the silt content in the argillanes should be $>50 \%$. Humus substances together with the silt fraction are accumulated in argillanes, as its humus content is $0.48-0.53 \%$, and within the illuvial horizon is $0.21-0.35 \%$. Since the profile-differentiated soils of the Precarpathian region are characterized by a fulvant type of humus $\left(\mathrm{C}_{\text {humic acid }}: \mathrm{C}_{\text {fulvo acid }}=0.3-0.5\right)$, fulvic acids that migrate from the $\mathrm{A} 1$ horizon are accumulated in the argillanes.
In order to establish the genetic nature of argillanes, a determination of their gross chemical composition and the surrounding horizon was made, and $\mathrm{Cx}$ was calculated on their basis (Table 2).

The obtained results indicate that half-oxides $\mathrm{Al}_{2} \mathrm{O}_{3}$ $(\mathrm{Cx}=1.32)$ and $\mathrm{Mn}_{3} \mathrm{O}_{4}(\mathrm{Cx}=2.00)$ are accumulated in argillanes. The accumulation of $\mathrm{MgO}, \mathrm{K}_{2} \mathrm{O}$ and $\mathrm{Na}_{2} \mathrm{O}$ in the argillanes is the result of the process of alkaline, alkaline ground elements leaching from the A1 horizon and their migration with the colloidal solutions within the profile. Such a pattern exists due to the fact that the silt fraction is composed mainly of clay minerals, which are characterized by high content of $\mathrm{Al}_{2} \mathrm{O}_{3}, \mathrm{Fe}_{2} \mathrm{O}_{3}, \mathrm{MgO}$ and $\mathrm{K}_{2} \mathrm{O}$. $\mathrm{SiO}_{2}$ compounds $(\mathrm{Cx}=0.93)$ do not accumulate in argillanes because of their larger size.

One of the most reliable and widespread methods for diagnosing the genetic nature of soils, the combined effect of all or individual BSPs, is the gross chemical analysis of the soil, its silt fraction and indicators calculated on its basis: molar ratio, EA- $\mathrm{Fe}_{2} \mathrm{O}_{3}, \mathrm{EA}-\mathrm{R}_{2} \mathrm{O}_{3}$, EAt and EAm (Table 3). In the absence of the technical feasibility of determining the mineralogical composition of the silt, we used the theoretical developments of the clay minerals characteristics by the ratio of $\mathrm{SiO}_{2}: \mathrm{Al}_{2} \mathrm{O}_{3}$. It was found that such a ratio in the silty fraction for koalin and branazine is 2.0 , for the group of mica and illites is 3.0-3.5, and for minerals of montmorillonite group is 3.5-4.0 (Sokolova, 2005). In the profile-differentiated soils of the Precarpathian region, the $\mathrm{SiO}_{2}: \mathrm{Al}_{2} \mathrm{O}_{3}$ ratio for the silty fraction within the profile is 3.73-3.87, which suggests that the minerals of the montmorillonite group, which are most labile and migrate during the process of lessivage, predominate in the silt. Approximately the same values of the ratio $\mathrm{SiO}_{2}: \mathrm{Al}_{2} \mathrm{O}_{3}$ indicate the predominance of montmorillonite group minerals within the entire profile. The diagnostic fea-

Table 1. The granulometric composition of argillanes and fine earth of the illuvial horizon in the profile-differentiated soils of the Precarpathian Region ( $\mathrm{n}=6)$

Tabelle 1. Granulometrische Zusammensetzung von Argillanen und der feinen Erde im Illuvialhorizont der profildifferenzierten Böden der vorkarpatischen Region ( $\mathrm{n}=6)$

\begin{tabular}{|c|c|c|c|c|c|c|c|c|}
\hline \multirow{4}{*}{$\begin{array}{l}\text { Depth of selection } \\
\qquad(\mathrm{cm})\end{array}$} & \multicolumn{7}{|c|}{ Particle size (mm), quantity (\%) } & \multirow{4}{*}{ Granulometric composition } \\
\hline & \multirow{2}{*}{\multicolumn{2}{|c|}{$\begin{array}{l}\text { Physical sand } \\
\text { Sand }\end{array}$}} & \multicolumn{4}{|c|}{ Physical clay } & \multirow{3}{*}{$\Sigma$ particles $<0.01$} & \\
\hline & & & \multicolumn{3}{|c|}{ Powder } & \multirow{2}{*}{$\begin{array}{c}\text { Silt } \\
<0.001\end{array}$} & & \\
\hline & $1-0.25$ & $0.25-0.05$ & $0.05-0.01$ & $0.01-0.005$ & $0.005-0.001$ & & & \\
\hline $\mathrm{Bm} \mathrm{g}(75-85)$ & 2.4 & 5.6 & 32.5 & 8.1 & 14.9 & 36.5 & 59.5 & Rough-powdered light-clayey \\
\hline Argillanes (75-85) & 1.0 & 2.2 & 16.1 & 4.4 & 15.8 & 60.5 & 80.7 & Silty hard-clayey \\
\hline
\end{tabular}


Table 2. Elements accumulation coefficient $(\mathrm{Cx})$ in the argillanes of the profile-differentiated soils of the Precarpathian region $(\mathrm{n}=6)$ Tabelle 2. Der Akkumulationskoeffizient von Elementen (Cx) in den Argillanen profildifferenzierter Böden der vorkarpatischen Region $(\mathrm{n}=6)$

\begin{tabular}{lllllllllll}
\hline Genetic horizon & $\mathrm{SiO}_{2}$ & $\mathrm{Al}_{2} \mathrm{O}_{3}$ & $\mathrm{Fe}_{2} \mathrm{O}_{3}$ & $\mathrm{R}_{2} \mathrm{O}_{3}$ & $\mathrm{TiO}_{2}$ & $\mathrm{CaO}$ & $\mathrm{MgO}$ & $\mathrm{K}_{2} \mathrm{O}$ & $\mathrm{Na}_{2} \mathrm{O}$ & $\mathrm{Mn}_{3} \mathrm{O}_{4}$ \\
\hline $\mathrm{Bmg}$ & 0.93 & 1.32 & 1.01 & 1.23 & 0.98 & 1.05 & 1.81 & 1.24 & 1.16 & 2.0 \\
\hline
\end{tabular}

ture of lessivage in the profile-differentiated soils of the Precarpathian region is equal distribution of $\mathrm{SiO}_{2}: \mathrm{R}_{2} \mathrm{O}_{3}$ within the profile in the silty fraction (3.01-3.04), the accumulation of $\mathrm{Fe}_{2} \mathrm{O}_{3}, \mathrm{R}_{2} \mathrm{O}_{3}$ within the illuvial portion in comparison with the rock, positive values of $\mathrm{EA}-\mathrm{Fe}_{2} \mathrm{O}_{3}$, EA- $\mathrm{R}_{2} \mathrm{O}_{3}$, EAt and EAm in the silty fraction in the illuvial part of the profile.

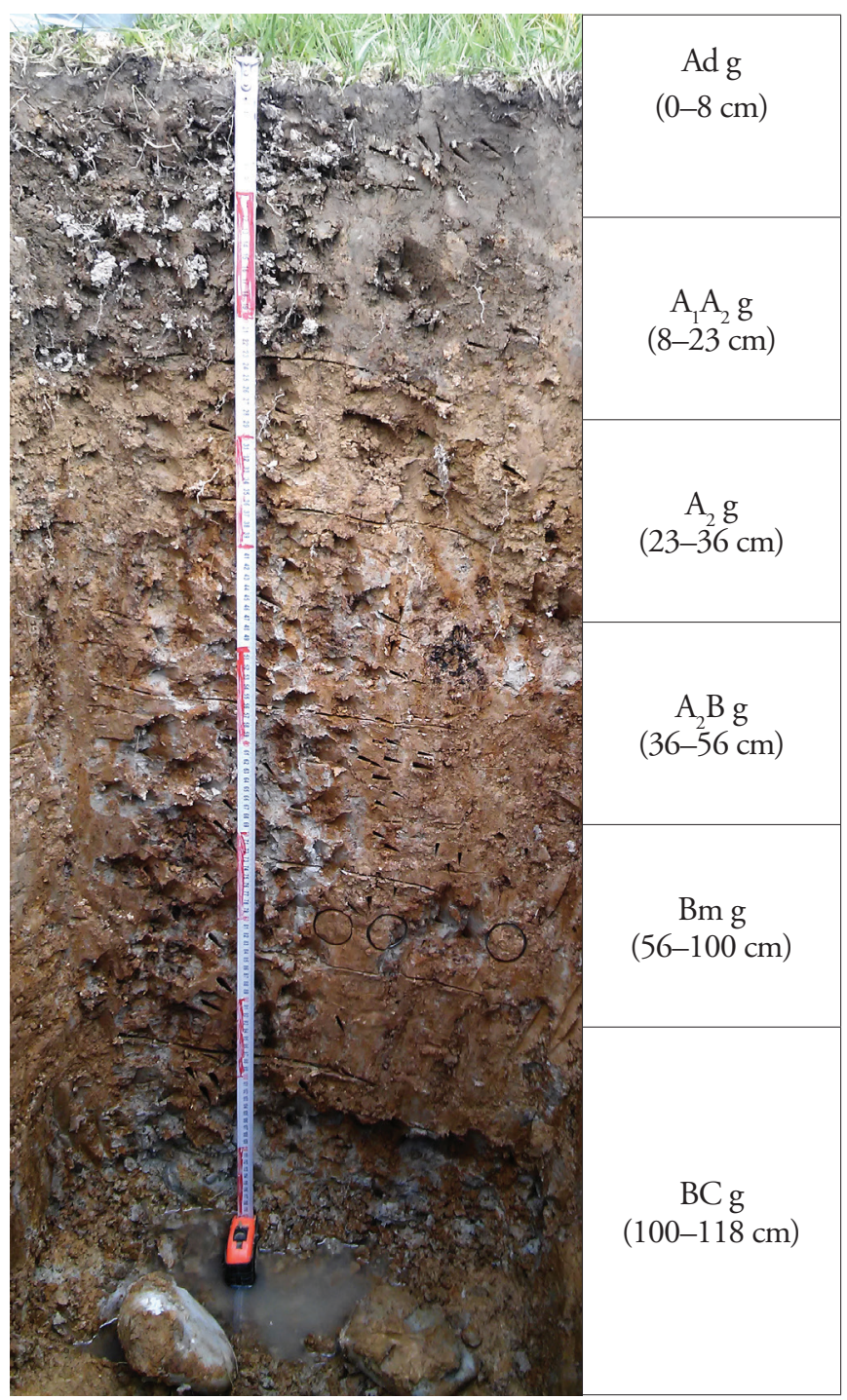

\section{Conclusion}

The genesis of the profile-differentiated soils of the Precarpathian region, which were formed as a result of the combined action of podzolization, lessivage, gley-eluvium, is the most controversial one in the Ukrainian soil science. For the diagnosis of basic soil processes, especially lessivage, researchers use differentiated diagnostic criteria that causes problems at the genetic and classification levels. On the basis of our own field and analytical studies, it is suggested to diagnose the lessivage process in the profiledifferentiated soils of the Precarpathian region with the presence of argillanes within the illuvial horizon, which have a heavier granulometric composition compared to the containing horizon, and the content of silt in argillanes should be $>50 \%$.

It is proved that the gross chemical composition of the soil's silt fraction and argillanes is the most informative criteria to diagnose lessivage processes within the profiledifferentiated soils of the Precarpathian region. Based on the presented researches, it was defined that the difference between the content of silt in the mudstone and the argillanes of the illuvial horizon in $20 \%$ and more can be stated about the passage of the lessivage process.

The accumulation of $\mathrm{SiO}_{2}(\mathrm{Cx}<1)$ is not typical for argillanes, but instead half-oxides $\mathrm{Al}_{2} \mathrm{O}_{3}, \mathrm{R}_{2} \mathrm{O}_{3}$ and alkaline ground elements are accumulated. The diagnostic feature of the lessivage is equal distribution of the montmorillonite group minerals within the profile, which is diagnosed by the ratio of $\mathrm{SiO}_{2}: \mathrm{Al}_{2} \mathrm{O}_{3}$ in the silty fraction (3.71-3.87) and has an equal distribution pattern within the profile. A reliable feature of lessivage in the studied soils is an equal distribution of the $\mathrm{SiO}_{2}: \mathrm{R}_{2} \mathrm{O}_{3}$ ratio in the silty fraction (3.01-3.04), the accumulation of $\mathrm{Fe}_{2} \mathrm{O}_{3}$ and $\mathrm{R}_{2} \mathrm{O}_{3}$ in the illuvial horizon in comparison with the rock that is diagnosed by their gross content. The positive values of EA- $\mathrm{Fe}_{2} \mathrm{O}_{3}, \mathrm{EA}-\mathrm{R}_{2} \mathrm{O}_{3}, \mathrm{EAt}$ and EAm in the silty fraction, which are diagnosed in the illuvial part of the profile, confirm the lessivage process.

Figure 2. Brown podzolic soil profile

Abbildung 2. Bodenprofil der Podsol-Braunerde 
Table 3. The diagnostic criteria of lessivage according to the gross chemical composition in the profile-differentiated soils of the Precarpathian region Tabelle 3. Diagnostische Kriterien der Lessivierung nach der chemischen Bruttozusammensetzung in profildifferenzierten Böden der vorkarpatischen Region

\begin{tabular}{|c|c|c|c|c|c|c|c|c|}
\hline $\begin{array}{c}\text { Horizon } \\
\text { (sampling depth, } \mathrm{cm} \text { ) }\end{array}$ & $\begin{array}{l}\mathrm{SiO}_{2} \\
\mathrm{R}_{2} \mathrm{O}_{3} \\
\text { in silt }\end{array}$ & $\begin{array}{l}\mathrm{SiO}_{2} \\
\mathrm{Al}_{2} \mathrm{O}_{3} \\
\text { in silt }\end{array}$ & $\begin{array}{c}\text { Content of } \\
\mathrm{Fe}_{2} \mathrm{O}_{3} \text { in fines } \\
(\%)\end{array}$ & $\begin{array}{l}\text { Content of } \\
\mathrm{R}_{2} \mathrm{O}_{3} \text { in fines } \\
(\%)\end{array}$ & $\begin{array}{l}\mathrm{EA}-\mathrm{Fe}_{2} \mathrm{O}_{3} \\
\text { in silt }\end{array}$ & $\begin{array}{c}\text { EA- } \mathrm{R}_{2} \mathrm{O}_{3} \\
\text { in silt }\end{array}$ & $\begin{array}{l}\text { EAt } \\
\text { in silt }\end{array}$ & $\begin{array}{l}\text { EAm } \\
\text { in silt }\end{array}$ \\
\hline $\begin{array}{c}A_{1} g \\
(8-23)\end{array}$ & 3.46 & 4.30 & 2.96 & 10.83 & -4.70 & -11.52 & -0.04 & -0.11 \\
\hline $\begin{array}{c}A_{2} g \\
(25-35)\end{array}$ & 3.01 & 3.87 & 4.12 & 12.58 & +24.48 & +3.20 & +0.01 & +0.03 \\
\hline $\begin{array}{l}\mathrm{A}_{2} \mathrm{~B} g \\
(40-50)\end{array}$ & 3.01 & 3.80 & 5.82 & 18.16 & +17.91 & +2.67 & +0.01 & +0.03 \\
\hline $\begin{array}{c}\mathrm{Bm} \mathrm{g} \\
(75-85)\end{array}$ & 3.01 & 3.73 & 5.28 & 17.75 & +18.87 & +4.45 & +0.02 & +0.05 \\
\hline $\begin{array}{c}\text { BC g } \\
(104-114)\end{array}$ & 3.01 & 3.75 & 5.42 & 17.69 & +21.34 & +4.55 & +0.03 & +0.06 \\
\hline $\begin{array}{c}\mathrm{Cg} \\
(120-130)\end{array}$ & 3.04 & 3.71 & 4.75 & 16.41 & - & - & - & - \\
\hline
\end{tabular}

\section{References}

Andrushchenko, H.O. (1970): Hrunty zakhidnykh oblastey URSR (Soils of the western regions of the USSR). Vol. 2, Za Vilnu Ukrainu Press Ltd., Lviv-Dublyany, p. 116.

Arynushkyna, E.V. (1970): Rukovodstvo po khimicheskomu analizu pochv (Soil Chemical Analysis Guide). Moscow University Press, Moscow, p. 488.

Bronnykova, M.A. and V.O. Targulyan (2005): Kutannyy kompleks teksturno-differentsirovannykh pochv (Kutan complex of the textural-differentiated soils). Academknyga Press, Moscow, p. 197.

Dawson, B.S.W., Ferguson, J.E., Campbell, A.S. and E.J.B. Cutler (1985): Distribution of elements in some Fe-Mn nodules and an iron-pan in some gley soils of New Zealand. Geoderma 35, 127-143.

Duchaufour, P. (1951): Lessivage et podzolisation. Revue Forestière Française 10, 18-27.

Fridland, V.M. (1985): Ob opodzolivanii i illimerizatsii (obezilivanii) (On podzolization and illimerization (degassing)). Pedology 1, 27-38.

Harrassowitz, H. (1926): Laterit. Fortschritte der Geologie und Palaeontologie, Bd IV, Hft. 14, Berlin, 253-566.

Horbunov, N.I. (1960): Metodika podgotovki pochv, gruntov, vzvesey rek i osadkov morey $\mathrm{k}$ mineralogich- eskomu analizu (Methods of preparing grounds, soils, suspension of rivers and sea sediments to the mineralogical analysis). Pedology 11, 79-84.

Jenny, H. (1931): Behavior of potassium and sodium during the process of soil formations. Research Bulletin of the Missouri Agricultural Experiment Station 162, 24-52.

Kachynsyi, N.A. (1965): Fizika pochvy (Soil physics). Vol. 1, High School Press, Moscow, p. 324.

Kubiena, W.L. (1956): Zur Mikromorphologie. Systematik und Entwicklung der rezenten und fossilen Lössböden. Eiszeitalter und Gegenwart 7, 102-112.

Mückenhausen, E. (1958): Der Wasserhaushalt der Pseudogley und dessen Bedeutung für die Pflanzen. Verhandlungen der zweiten und vierten Kommission der Internationalen Bodenkundlichen Gesellschaft, Hamburg, 105-111.

Nazarenko, I.I. (1981): Okul'turivaniye podzolistikh ogleyennikh pochv (The cultivation of gley podzolic soils). Nauka, Moscow, p. 184.

Pankiv, Z.P. and S.P. Poznyak (1998): Dernovo-pidzolysti poverkhnevo-ohleyeni hrunty pivnichno-zakhidnoho Peredkarpattya (Sod-podzolic surface-gleyed soils of the north-western Precarpathian region). Merkator Press, Lviv, p. 132. 
Polchyna, S.M. and I.S. Smaga (2009): Diahnostyka profil'no-dyferentsiyovanykh gruntiv Peredkarpattya na osnovi yikh valovoho khimichnoho skladu (Diagnostics of the profile-differentiated soils of the Precarpathian region on the basis of their gross chemical composition). Yuriy Fedkovych Chernivtsi National University Scientific Journal 455, 111-115.

Rode, A.A. (1984): Genezis pochv i sovremennyye protsessy pochvoobrazovaniya (Soil Genesis and Modern Soil Formation Processes). Nauka, Moscow, p. 256.

RodeA.A.(2008): Izbrannyyetrudy. Podzoloobrazovatel'nyy protsess (Selected Works. Podzol formation process). Publishing House of Institute of Soil Science named after Dokuchaev, Moscow, p. 480.

Rozanov, B.H. (1988): Morfologiya pochv (Soil morphology). Moscow University Press, Moscow, p. 320.

Smaga, I.S. (2016): Problemy diahnostyky elementarnykh gruntovykh protsesiv i profil'no-dyferentsiyovanykh gruntiv u Peredkarpatti (The diagnostics problems of elementary soil processes and profile-differentiated soils in the Precarpathian region). Pedology 1-2, 40-48.
Smaga, I.S. (2008): Problemy identyfikatsiyi kyslykh ohleyenykh profil'no-dyferentsiyovanykh gruntiv Peredkarpattya (The identification problems of acid gleyed profile-differentiated soils of the Precarpathian region). Agro-Chemistry and Pedology 69, 142-146.

Sokolova, T.A., Dronova T.Y. and I.I. Tolleshta (2005): Glinistyye mineraly v pochvakh (Clay minerals in soils). Gryf and K Press, Tula, p. 336.

Targulyan, V.O. (1985): Pochvoobrazovaniye i elementarnyye pochvoobrazovatel'nyye protsessy (Soil formation and elementary soil formation processes). Pedolody 11, 36-45.

Zaydelman, F.R. (1973): Diagnostika podzolistykh i lessivirovannykh, psevdopodzolistykh, psevdogleyevykh i ogleyennykh podzolistykh pochv na sovremennom etape (Diagnostics of podzolic and lessivaged, pseudopodzolic, pseudo-gley and gley podzolic soils at the present stage). Pedology 1, 130-140.

Zonn, S.V. (1994): Razvitiye geneticheskoy díagnostiki pochv na osnove yelementarnikh pochvennykh protsessov (Development of the genetic soil diagnostics based on the elementary soil processes). Pedology 4, 12-20. 